\title{
Shifting Tides: The Port City of Mombasa and the First World W AR
}

\author{
Daniel Steinbach \\ University of Copenhagen
}

\begin{abstract}
Port cities across the world were deeply affected by the First World War. They had to adapt quickly to the influx of soldiers and labourers, as well as to resulting population changes that challenged and strained local structures. The pressure of these changes was especially felt in colonial port cities, as new arrivals - from abroad and from the hinterland - had the potential to undermine colonial order and control. In the period of 1914-1918 colonial authorities around the Indian Ocean saw local concerns regarding order and control overridden by global developments and imperial demands.

Mombasa, located on the East African coast, provides a potent example of this situation. In the war years, Mombasa turned into a military hub, with thousands of troops passing through it to serve in the East African campaign. These external arrivals were mirrored by the movement of people from the hinterland into the city seeking to fill positions in the local war economy. In this dynamic context, racial borders, social conventions, and economic patterns were continually challenged and transgressed. This article explores these developments and reactions they triggered among Indians, Africans, and Europeans in Mombasa at the time of the global war.
\end{abstract}

The First World War turned the Indian Ocean into one of the world's most crossed bodies of water. Ships transported millions of soldiers and labourers, as well as cargo, to and from theatres of war situated on, or accessed through, the Indian Ocean. ${ }^{1}$ Britain especially

\footnotetext{
${ }^{1}$ For recent scholarship on the Indian Ocean see: Sugata Bose, A Hundred Horizons: The Indian Ocean in the age of global empire (Cambridge, MA: Harvard University Press, 2006); Thomas R. Metcalf, Imperial Connections: India in the Indian Ocean arena, 1860-1920 (Berkley, CA: University of California Press, 2008); Michael Pearson, The Indian Ocean (London: Routledge, 2003); Edward A. Alpers, The Indian Ocean in World History (Oxford: Oxford University Press,
}

(C) Daniel Steinbach. This is an Open Access article distributed under the terms of the Creative Commons License CC BY NC SA, which permits users to share, use, and remix the material provided they give proper attribution, the use is noncommercial, and any remixes/transformations of the work are shared under the same license as the original. 
mobilised its empire across these waters, drawing on South Asian, African, and Australian colonial subjects for the war effort. After August 1914, large port cities like Bombay, Colombo, Aden, Durban, and Cape Town had to adapt quickly to an influx of material and people that stretched and strained existing systems and structures. Although most ports on the Indian Ocean were far removed from direct military action, Suez in Egypt and - later - Basra in Mesopotamia played important frontline roles in the Allied conquest of the Ottoman Empire. Similarly, Mombasa in British East Africa (today Kenya) became central for the British-led occupation of neighbouring German East Africa (today mainland Tanzania, Burundi, and Rwanda), the most important African theatre of war.

This war, with its global reach and totality, challenged multiple dimensions of life. War interrupted established trade networks, produced abrupt changes to agricultural and industrial production, and altered or destroyed infrastructure. Port cities were particularly affected by these challenges due to their commercial importance and role as transport and communication hubs. But port cities were equally hubs for the movement of people and ideas. For the many men - and some women - who left their homelands for the first time, ports were not only gateways to the war, but also portals through which to encounter people of different nationalities, races, classes, ethnicities, languages, and religions. ${ }^{2} \mathrm{With}$ these people, information also flowed in the form of news, propaganda and political content. Maintaining functional ports, and controlling the flow material, people, and ideas through them, was imperative for the colonial powers. Yet, despite the many unique features of port cities during the First World War, surprisingly little systematic attention has been paid to their role in the war or to the war's impact on these cities themselves. ${ }^{3}$

In order to begin addressing this gap in scholarly attention, the current article focuses on the case of Mombasa. In the early twentieth century, Mombasa (with its Mombasa and Kilindini harbours) was the most important East African port on the Indian

2014); Markus P. M. Vink, "Indian Ocean studies and the "new thalassology", Journal of Global History, 2,1 (2007), 4162. For Africa and the Indian Ocean in particularly, see: Isabel Hofmeyr, Uma Dhupelia-Mesthrie and Preben Kaarsholm, "Durban and Cape Town as port cities: Reconsidering southern African studies from the Indian Ocean," Journal of Southern African Studies, 42, 3 (2016), 375-87; Gwyn Campbell, Africa and the Indian Ocean world from early times to circa 1900 (Cambridge: Cambridge University Press, 2019). No specific research exists on the Indian Ocean during the First World War.

${ }^{2}$ For a recent overview, see: Santanu Das, Anna Maguire, Daniel Steinbach, (eds.), Colonial Encounters in a Time of Global Conflict, 1914-1918 (London: Routledge, 2021).

${ }^{3}$ For two recent examples with an emphasis on the international character of these spaces, see: Valeska Huber, "Connecting colonial seas: The 'international colonisation' of Port Said and the Suez Canal during and after the First World War,"

European Review of History: Revue europeenne d'histoire 19, 1 (2012), 141-61; Tobit Vandamme, "The rise of nationalism in a cosmopolitan port city: The foreign communities of Shanghai during the First World War," Journal of World History 29,1 (2018), 37-64. 
Ocean. ${ }^{4}$ Having only recently lost its status as capital city to Nairobi, Mombasa was in 1914 still the economic centre of British East Africa. The city was also defined by its heterogeneous population: ${ }^{5}$ The African population consisted of various ethnic groups, including coastal 'Swahilis' and migrants from the hinterland. Europeans may have been the smallest group within the city, but they were politically and economically dominant, and held all of the influential positions in Mombasa's colonial hierarchy. As settlers, traders, missionaries and officials, members of this group were linked via networks, societies, and organisations to European colonial peoples and institutions in other parts of Africa and in Europe. ${ }^{6}$ A small, but significant, Arab population represented the former precolonial elite with established relations along the coast. Mombasa was also home to around 8000 Indians, working mainly as wholesale merchants, railway workers, smallscale traders, and artisans. ${ }^{7}$ Some had been resident of the city for generations; others were more recent arrivals from India. This population linked Mombasa and its hinterland to the west coast of India. As Charles W. Hobley, the Mombasa-based Provincial Commissioner of the Coast Province (Seyidie) and one of Kenya's most influential early colonial administrators, noted:

The people of Mombasa are of many races, and comprise all sorts and conditions of men. We have the high-born Arab cheek to jowl with the uncivilised Mdigo, the more or less educated Swahili, and the Kikuyu gharry boy. The result of this association of peoples has been a general trend to the growth of a hybrid civilization. ${ }^{8}$

\footnotetext{
${ }^{4}$ The two most important books on Mombasa are still: Frederick Cooper, On the African Waterfront: Urban disorder and the transformation of work in colonial Mombasa (New Haven, CT: Yale University Press, 1987); Justin Willis, Mombasa, the Swahili and the Making of the Mijikenda (Oxford: Clarendon Press, 1993).

${ }^{5}$ There are no precise figures for the population of Mombasa at the time, but the town had circa 30,000 inhabitants $(20,000$ Africans, 8,000 Indians, 1,000 Arabs, and 500 Europeans). A note on the language: I am conscious that terms like 'white,' 'European,' 'coloniser,' and 'black,' 'African,' 'Indian,' 'colonised' represent a constructed racial and power polarity. While using these terms without quotation marks, I am nonetheless aware of the problematic concepts behind them. ${ }^{6}$ Dane Kennedy, Islands of White: Settler society and culture in Kenya and Southern Rhodesia, 1890-1939 (Durham, NC: Duke University Press, 1987); Bruce Berman and John Lonsdale, Unhappy Valley: Conflict in Kenya and Africa, 2 vols. (London: James Currey, 1992).

${ }^{7}$ For an overview on Indians in East Africa: J. S. Mangat, A History of the Asians in East Africa, 1886-1945 (Oxford: Clarendon Press, 1969); Robert G. Gregory, India and East Africa: A History of Race Relations within the British Empire, 1890-1939 (Oxford: Clarendon Press, 1971); Metcalf, Imperial Connections; Sana Aiyar, Indians in Kenya. The politics of diaspora (Cambridge, MA: Harvard University Press, 2015).

${ }^{8}$ Annual Report 1917/18 for Seyidie Province (Mombasa) by P.C. Hobley, n.d. 1918, Kenya National Archives (hereafter: KNA) PC/Coast/1/12/260.
} 
Hobley's description could be read in many ways. However, his reaction to this intermingling of people was likely a critical one, given his strong paternalistic belief in protecting 'traditional' African societies from outside influences exerted by European missionaries and settlers or by Indian traders, and in preventing the 'mixing' of different ethnic groups. ${ }^{9}$

This particular mixture of people, though by no means unique in a colonial port city, makes Mombasa an interesting setting within which to explore how warfare between European powers refracted through the multiple layers and divisions within East African society. In this article, I focus on how the movement of people into this port city - both from the interior of the colony and from across the Indian Ocean, in combination with the general context of a war fought between European powers - created challenges for colonial power and control. ${ }^{10}$ Although port cities were accustomed to a certain degree of diversity in people and ideas, the radical shift in the flow of such people and ideas, precipitated by the global war, was a new and unbalancing experience. In this destabilised context, I explore how authorities reacted in formal and informal ways to regain control over the structures of colonial society.

The research base, upon which I draw, brings together a diverse range of sources. On the one hand, there are official government files centred around the correspondence and reports by and with the Provincial Commissioner held at the Kenya National Archives, material from the India Office Records at the British Library, and local newspapers. Yet, despite the diverse locations and forms of this documentary material, the voices it contains are almost exclusively European. To overcome the silence of Indians and Africans, I read these sources somewhat 'against the grain,' even though colonial perceptions and motivations form a core feature of the article. ${ }^{11}$ Additionally, I have utilised the memoir of Lalchand Sharma, an Indian who had moved from the Punjab to British East Africa to work as a construction labourer on the Uganda railway line. Towards the end of his life he wrote a detailed account on his experience during the war and his imprisonment in Mombasa, providing a very rare subaltern perspective on this period. ${ }^{12}$

\footnotetext{
${ }^{9}$ A.T. Matson and Thomas P. Ofcansky, “A bio-bibliography of C.W. Hobley,” History in Africa, 8 (1981), $253-60$.

${ }^{10}$ Frederick Cooper and Ann L. Stoler, "Introduction tensions of empire: Colonial control and visions of rule," American Ethnologist 16 (1989), 609-21; Ashwini Tambe and Harald Fischer-Tiné, (eds.), The Limits of British Colonial Control in South Asia: Spaces of disorder in the Indian Ocean region (Routledge, 2008).

${ }^{11}$ For a recent discussion, see: Ricardo Roque and Kim A. Wagner, (eds.), Engaging Colonial Knowledge: Reading European archives in world history (Basingstoke: Palgrave Macmillan, 2012).

${ }^{12}$ I am extremely thankful to Dr. V. B. L. Sharma for sharing his father's unpublished manuscript with me. He is planning a publication under the title "Prisoners of Tsavo: An account of persecution and survival in colonial Africa."
} 


\section{Mombasa AT WAR}

The outbreak of war between Britain and Germany transformed East Africa. It became one of the most important theatres of war outside Europe, ${ }^{13}$ and in so doing shifted its position on the 'periphery of the Indian Ocean World' to being one of its epicentres. ${ }^{14} \mathrm{War}$ also came at a sensitive time for British East Africa. A decade-long, and increasingly bitter, campaign about the settlement and political rights of Indians in the colony had impacted nearly all aspects of public and political debate. ${ }^{15}$ While the focus of this struggle centred on the highlands around Nairobi, a number of influential Indian merchants, under the leadership of A.M. Jeevanjee, founded the 'East African Indian National Congress' in Mombasa in March 1914. The main aim of this organisation was to prevent European settlers and their supporters from turning British East Africa into a 'white colony' by curbing immigration from India and excluding Indians from meaningful political participation. ${ }^{16}$ At this point in time, Europeans likely felt that Indian, but also increasingly African, trade competition was challenging their economic ascendancy and position at the top of the political and social hierarchy.

These rising local tensions during the summer of 1914 were reflected in the reaction to the outbreak of hostilities. In response to the news of war in Europe, leading voices among white colonial settlers affirmed their patriotic loyalty to Britain and to the war effort, but also warned against the colony's active military participation in it. ${ }^{17}$ Dreading that an armed conflict might erode their political and economic power, they declared that 'this war fever is uncomfortable, and if it is not needed, why interfere with trade, anyway, till it is absolutely necessary. ${ }^{, 18}$ As important - if not more so - than commercial concerns were anxieties about a potential uprising by the colonised African - and potentially Indian - population, who might capitalise on the distraction of war and rebel against the colonial

\footnotetext{
${ }^{13}$ Hew Strachan, The First World War in Africa (Oxford: Oxford University Press, 2004); Edward Paice, Tip and Run: The untold tragedy of the Great War in Africa (London: Weidenfeld and Nicolson, 2007); Michelle Moyd, "Centring a sideshow: Local experiences of the First World War in Africa," First World War Studies, 7, 2 (2016), 111-30.

${ }^{14}$ Edward A. Alpers, East Africa and the Indian Ocean (Princeton, NJ: Markus Wiener, 2009), vii.

${ }^{15}$ Gregory, India and East Africa, 154-5; Aiyar, Indians in Kenya, 60-2.

${ }^{16}$ Meetings of the East African Indian National Congress, KNA MAC/EAI/28/1. See also: Gregory, India and East Africa, 93-4.

${ }^{17}$ Kent Forster, "The quest for East African neutrality in 1914," African Studies Review 22, 1 (1979), 73-82; Daniel Steinbach, "Power majorities and local minorities: German and British colonials in East Africa during the First World War," in Germans as Minorities During the First World War: A global comparative perspective, ed. Panikos Panayi (Farnham: Ashgate, 2014), 263-88.

${ }^{18}$ Leader of East Africa (8 Aug. 1914). For a recent overview on deep-seated European concerns about the loss of control, see: Harald Fischer-Tiné, (ed.), Anxieties, Fear and Panic in Colonial Settings: Empires on the verge of a nervous breakdown (Basingstoke: Palgrave Macmillan, 2016).
} 
regime. These sentiments fit within a more general concern in the colonial sphere, and especially in Africa, over the consequences of conflict between European powers something that threatened both the ideological justification for colonial rule, in which Europeans positioned themselves as the bringers of peace and civilisation to 'the dark continent,' and the authority of 'white prestige' with which that rule was exerted. For these reasons, the European colonial powers in general, and 'men on the spot' in particular, preferred to think of themselves as allies in a broader battle to control and tame Africa and Africans. ${ }^{19}$

Any hopes for 'colonial neutrality' disappeared within days, and Mombasa - along with the rest of British East Africa - shifted into war in August 1914. In response, the town saw the formation of two citizen militias: the 'Mombasa Town Guard' of European volunteers and the 'Indian Volunteer Force'. ${ }^{20}$ Founded as expressions of patriotism and loyalty, both units held regular public parades. British military volunteers from Mombasa were quickly incorporated into in the East African Mounted Rifles, a new military unit composed largely of white settlers. By contrast, all local Indian volunteer units were disbanded after three months, against the explicit wishes of the Indian residents. This decision was rooted less in military concerns than it was in political anxieties. Any display of power by local Indians was threatening to the already challenged status of British settlers in the colony. Excluded from active war service, the Indian population was pushed into a corner in which they could not so easily claim to be patriots, and were therefore easily framed as anti-patriotic. Indeed, British colonial settlers accused them of raising prices and 'reaping the harvest' as war profiteers, a notion that remained a common trope throughout the war and after as well. ${ }^{21}$

\section{Arrivals From Across the OCean}

In the first weeks of the war, life in the city was overshadowed by grave concerns about the war's impact on commercial activities and the possibility of a German naval or land attack. The local newspaper declared: 'Mombasa certainly looks very gloomy, nearly everything coming to a standstill. ${ }^{22}$ This mood shifted with the arrival of troops from

\footnotetext{
${ }^{19}$ Michael Adas, "Contested hegemony: The Great War and the Afro-Asian assault on the civilizing mission ideology," Journal of World History, 15, 1 (2004), 31-63.

${ }^{20}$ See: File "Indian volunteers," KNA PC/Coast/1/13/112.

${ }^{21}$ Gregory, India and East Africa, 150-151; Sana Aiyar, "Empire, race and the Indians in colonial Kenya's contested public political sphere, 1919-1923,” Africa, 81, 1 (2011), 132-154.

${ }^{22}$ Leader of East Africa (8 Aug. 1914).
} 
India in September 1914. The Indian Army played a crucial role in the defence of the British Empire on the Western Front and beyond, and their deployment to East Africa was part of an overall imperial strategy to swiftly conquer all German colonies. ${ }^{23}$ Deployment of Indian soldiers for imperial wars had a long tradition, and the loyalty and professionalism of the Indian Army were regularly celebrated in imperial propaganda. ${ }^{24}$ Yet, the reaction to the arrival of troops from India was mixed among the white population of British East Africa. ${ }^{25}$ On the one hand, public opinion welcomed the support of professional soldiers who would defend the colony. On the other, there was the fear that this Indian contribution would be leveraged as a bargaining tool for increased rights by local Indians in Britain's East African colonies. Both of these sentiments were especially evident in Mombasa, which was the embarkation point for Indian troops, but also the place where local residents were most fearful of German attack. For the local colonial authorities, however, the most salient concern was over how the arrival of the Indian soldiers would affect the town's Indian and African populations.

Mirroring the general support for the British war effort since August 1914, the leading Indian residents of Mombasa, the owners of merchant houses, expressed their pride and allegiance to the Empire. At least some ordinary Indian residents shared this sentiment with the Indian elite and engaged in their own displays of loyalty. In September 1915, for example, more than 600 Hindus - alongside Sikhs and Jains - gathered at Mombasa's temple to pray 'to God to give success to the Emperor [of India], his army and arms.' 26 Throughout the war, money collections were held by the town's Indian population in support of the troops, but these donations were reserved for 'Asiatic and European' soldiers, excluding Africans. ${ }^{27}$ Thus, fundraising for the war effort fitted into the political aims of local Indian groups, who sought to redraw racial lines to include white and Indian residents in the same category of 'imperial citizen,' at the exclusion of Africans.

\footnotetext{
${ }^{23} 47,000$ Indian men ( $3 / 4$ combatants and 1/4 non-combatants) and 5,500 British men were sent from India to serve in the East African campaign. See: S. D. Pradhan, Indian Army in East Africa, 1914-1918 (New Delhi: National Book Organisation, 1991); Santanu Das, India, Empire, and First World War Culture: Writings, images, and songs (Cambridge: Cambridge University Press, 2018); Kaushik Roy, Indian Army and the First World War, 1914-18 (Oxford University Press, 2018), 167-201.

${ }^{24}$ Bose, A Hundred Horizons, 122-147; Metcalf, Imperial Connections, 68-102; Robert J. Blyth, The Empire of the Raj: India, Eastern Africa and the Middle East, 1858-1947 (Basingstoke: Palgrave Macmillan, 2003), 76-90

${ }^{25}$ Daniel Steinbach, "Between intimacy and violence: Imperial encounters in East Africa during the First World War," in Colonial Encounters in a Time of Global Conflict, eds. Das, Maguire, and Steinbach.

${ }^{26}$ The East African Standard (2 Oct. 1915).

${ }^{27}$ Letter from P.C. Hobley to Col. Vickers, O.C. Troops, Mombasa, 24 Dec. 1915, KNA PC/Coast/1/3/78. This is a continuation of pre-war developments, see: Aiyar, Indians in Kenya, 50-4. The sentiment was shared by Indian soldiers serving in Africa, see: Bose, A Hundred Horizons, 129-30.
} 
Any expectations among Mombasa's Indian elite that these displays of solidarity and support might lead to a relaxing of racial boundaries were, however, to be disappointed. For example, in January 1915 the Mombasa Club, the exclusive white bastion of social life, discussed a proposal to allow Indian officers and local Indians with 'the rank of superior officer' to become eligible as members for the club. The club's members voted down this proposal. However, they did grant membership to other Allied officers - and they did not expel German members of the club until later that year. ${ }^{28}$ Apparently, Europeans belonging to the enemy camp were preferable to loyal local Indians and Indian officers fighting on behalf of the British. Even at this time of crisis, racial identity trumped imperial solidarity.

For the majority of Mombasa's Indian residents, the war resulted in even greater restrictions of their freedoms. In part, this resulted from the colonial government's imposition of martial law to simplify the increasingly entangled responsibilities of civilian and military authorities. ${ }^{29}$ Additionally, the authorities had become concerned that the influx of outsiders unfamiliar with local norms (i.e. of upholding racialised boundaries) would undermine established more 'informal' forms of control. ${ }^{30}$ The martial law specifically included regulations to alter the use and control of public spaces and transportation. For example, 'non-Europeans' were now banned from accessing certain railway platforms and boat terminals. This codification of unequal treatment between Europeans and Indians, and the creation of a shared category of 'Africans and Asians,' clearly contradicted the aspirations of the Indian community and caused widespread resentment. Retaliatory rumours about mistreatment of Indian women and high-class Indians meandered throughout Mombasa in the subsequent months. ${ }^{31}$

Along with increasing control over the urban population, the colonial authorities also created propaganda, both in print and through public ceremonies, to quell any proGerman or anti-British sentiments, and to keep Mombasa's population on the side of the war effort. ${ }^{32}$ In 1916, a public 'baraza' (council) was held by Governor Sir Henry Belfield at the new market in Salim Road in the centre of town. During this event, supposedly German anti-Islamic propaganda was recited, distributed and displayed in order to counter

\footnotetext{
${ }^{28}$ Edward Rodwell, The Mombasa Club (Mombasa: Rodwell Press, 1988), 33-42.

${ }^{29}$ Charles Dundas, African Crossroads (London: Macmillan, 1955), 80.

${ }^{30}$ Notices by H. Vickers, Lt. Col. Commanding Mombasa, 4 and 28 Aug. 1915, KNA PC/Coast/1/10/210.

${ }^{31}$ Letter from B.J. Bhishe (Sec. of Hindi Merchants and Brokers Association) to Chief Sec., Mombasa, 8 Oct. 1915, KNA PC/Coast/1/1/314.

${ }^{32}$ For an overview, see: Erik-Jan Zürcher, (ed.), Jihad and Islam in World War I: Studies on the Ottoman Jihad on the centenary of Snouck Hurgronje's 'Holy War made in Germany' (Leiden: Leiden University Press, 2016).
} 
the narrative of German support of Muslims. ${ }^{33}$ In addition to their religion, the East African government appealed to Indians' emotional links to India itself. In spring 1918, the government printed two hundred leaflets containing a Gujarati translation of an older British newspaper article titled 'Kaiser planned Plunder of India,' and handed them out in town. ${ }^{34}$ The reach and effect of these propaganda efforts among ordinary residents is impossible to assess in isolation. Regardless, the leading figures of Mombasa's Indian traders remained dedicated to the war effort as a means to improve conditions for Indians in British East Africa. In addition, with the increasing British military successes, they began to advocate for turning recently occupied German East Africa into an Indiancontrolled colony. ${ }^{35}$

Certainly, not all Indian residents of Mombasa supported the notion of a shared cause of imperial defence, nor were they vexed only by the petty racism displayed in public life. Pre-war agitation demanding access to political power continued and grew during the war. In India itself - fanned partly by German propaganda efforts - antiimperial activities increased. Colonial governments became concerned over how these ideas might travel with Indian soldiers as they moved across the Empire. ${ }^{36}$ One of the centres of these anti-imperial activities was the Ghadr movement, which planned a violent overthrow of British rule in India from its headquarters in California. ${ }^{37}$ In British East Africa the movement had a small number of supporters among Hindus and Sikhs from the Punjab whose undertakings the colonial state closely observed.

In Mombasa, military and civilian authorities cooperated to uncover political activists and agitators among both established Indian civilians and the continuous stream of arriving soldiers from India. One well-documented case was of Tirath (Sita) Ram, a railway clerk arrested in early 1915, for 'endeavouring to excite enmity between the

\footnotetext{
${ }^{33}$ Letters from P.C. Hobley to editor of Leader of East Africa, the Liwali of Mombasa, Chief Justice and all high government officials, Mombasa (19 Sep. 1916), KNA PC/Coast/1/13/64.

${ }^{34}$ Letter from G.S.O. King's African Rifles to P.C. Mombasa, Nairobi (23 Apr. 1918), KNA PC/Coast/1/13/58. See also: Herbert Lüthy, "India and East Africa: Imperial partnership at the end of the First World War," Journal of Contemporary History, 6, 2 (1971), 55-85.

${ }^{35}$ For the extensive inter-imperial discussions on the future of German East Africa, see: Gregory, India and East Africa, 156-76; Blyth, The Empire of the Raj, 93-131.

${ }^{36}$ Harald Fischer-Tiné, "Indian nationalism and the world forces: Transnational and diasporic dimensions of the Indian freedom movement on the eve of the First World War," Journal of Global History, 2 , 3 (2007), 325-44; Jennifer Jenkins, Heike Liebau, and Larissa Schmid, "Transnationalism and insurrction: Independence committees, anti-colonial networks, and Germany's global war," Journal of Global History, 15, 1 (2020), 61-79.

${ }^{37}$ Aiyar, Indians in Kenya, 61-2; Maia Ramnath, "Two revolutions: The Ghadar movement and India's radical diaspora, 1913-1918," Radical History Review, 92 (2005), 7-30. For an overview, see: Maia Ramnath, Haj to Utopia: How the Ghadar Movement charted global radicalism and attempted to overthrow the British Empire (Berkeley, CA: University of California Press, 2011).
} 
Indian population of British East Africa' and the government. He - and his co-accused Ram Lal Sapru - had several copies of the Ghadr newspaper in their possession, with the instructions to 'distribute these papers and pamphlets to all Indians more especially amongst the Indian soldiers. ${ }^{38}$ This case occurred at a time of heightened alert for the colonial governments across the British Empire in response to the mutiny of Indian troops stationed in Singapore in February 1915. ${ }^{39}$ Hence the governor decided in March 1915 that 'in view of the presence of large numbers of Indian troops,' a swift deportation of Ram from British East Africa to India was necessary to avoid any disorder in Mombasa. ${ }^{40}$ Over the course of the year, at least ten Indian civilians in Mombasa were arrested and prosecuted for 'circulating or having in their possession seditious publications,' among them the owners of a printing press. ${ }^{41}$

In addition to these cases, at least six Indians were found guilty of 'actively assisting the enemy' at courts martial and sentenced to death. ${ }^{42}$ While two of those had their sentences commuted to terms of imprisonment, two were hastily shot by a firing squad, and two weeks later, a further two - Allidina Dhalla and Bishen Singh - were sentenced to be hanged in Mombasa in November 1915. The military authorities, represented by the General Officer Commanding, intended to utilise these executions as public displays of British power and control, especially since sections of Mombasa's Indian population had shown their support for the condemned prisoners by handing them flower garlands and mangoes on their way to the prison. ${ }^{43}$ In a display of colonial power, Mombasa's civil authorities ordered the town's inhabitants to attend the public hanging, and employed soldiers to gather a large crowd of Africans and Indians to witness it. ${ }^{44}$

There is no evidence of any Indian-African cooperation to undermine the war effort, let alone of coordinated attempts to overthrow British colonial control. Yet, these

\footnotetext{
${ }^{38}$ Statement by William K. Notley, Commissioner of East African Police, 3 May 1915, India Office Records in the British Library (hereafter: IOR) L/PJ/6/1377.

${ }^{39}$ Heather Streets-Salter, "The local was global: The Singapore mutiny of 1915," Journal of World History, 24, 3 (2013), $539-76$.

${ }^{40}$ Letter from Governor H.C. Belfield to Secretary of State for the Colonies Lewis Harcourt, 20 May 1915, $\mathrm{IOR} / \mathrm{L} / \mathrm{PJ} / 6 / 1377$.

${ }^{41}$ These men, sentenced to five to fifteen years' imprisonment respectively, were released after the war on the condition that they proceeded to India and not return to East Africa. See: Report of a Committee appointed to consider the release of Prisoners sentenced under Martial Law, 1 Apr. 1919, KNA AG/16/210.

42 "Sedition among Indians in British East Africa" Circular No. 2 (1916) by Criminal Intelligence Office; The National Archive (hereafter: TNA), CO/537/773.

${ }^{43}$ Unpublished manuscript by Lalchand Sharma.

${ }^{44}$ Telegram from Staff Captain to P.C. Mombasa, Voi, 11 Nov. 1915, KNA PC/Coast/1/3/77. For a discussion on the First World War period as a turning point in public executions, see: Stacey Hynd, "Murder and mercy: Capital punishment in colonial Kenya, ca. 1909-1956," International Journal of African Historical Studies, 45, 1 (2012), 81-101.
} 
possibilities clearly troubled the local administration. Provincial Commissioner Hobley, argued that imprisoned Indians 'convicted of disloyal conduct and sedition [were] not a desirable element in our goals,' as they would come in close contact with African prisoners. It would be impossible to 'prevent verbal communications between such prisoners and the African convicts,' and the spread of revolutionary ideas would be unavoidable. To avert short- and long-term harm to British rule, he demanded that all 'political prisoners' be deported to India to serve their sentences there. ${ }^{45}$ The removal of prisoners from one colony and shipping them across the Indian Ocean to be interned somewhere else was a common practice in the British Empire. ${ }^{46}$ However, concerns about the spreading of rebellious ideas across racial lines was not shared by all decision makers in British East Africa, and even the Attorney General firmly believed that 'the African is not likely to be beguiled by the Indian. ${ }^{47}$ Perhaps reflecting this ambivalence, but also financial considerations and the shortage of transport, only a few high-profile prisoners were deported from Mombasa during the war. The majority of convicts were only removed from East Africa after the end of hostilities. ${ }^{48}$

Those Indian 'political prisoners' who were not deported to India were held in the Mombasa prison in Fort Jesus. One of them - Lalchand Sharma - later wrote a detailed account of his experience during the war and his imprisonment, providing a rare subaltern perspective. ${ }^{49}$ According to Sharma most of the Indian prisoners considered themselves victims of settler-inspired intrigues and were not released only because the government was keen to avoid admitting errors of justice. The colonial authorities even used the Indian prisoners in public demonstrations of colonial order and power, for example by forcing them to carry out road maintenance work in town. However, this practice was perceived as degrading not just for the prisoners themselves, but for the town's Indian population in general, as this type of forced labour was generally carried out by African convicts. Several influential Mombasa Indians successfully petitioned the District Commissioner Charles Dundas to terminate this practice.

\footnotetext{
${ }^{45}$ Letter from P.C. Mombasa to Chief Sec. via Attorney General, 16 Dec. 1915, KNA AG/16/386.

${ }^{46}$ Clare Anderson, Subaltern Lives: Biographies of colonialism in the Indian Ocean world, 1790-1920 (Cambridge: Cambridge University Press, 2012), 1-22.

${ }^{47}$ Comment by Attorney General to Chief Sec., 23 Dec. 1915, KNA AG/16/386

${ }^{48}$ In spring 1919, seven Indian political prisoners convicted by military court martial for 'having in possession seditious publications likely to promote dissatisfaction or bad feeling' had their sentences shortened and were deported to India and barred from returning to East Africa. See: Letter from Governor Edward Northey to Secretary of State for Colonies, 6 May $1919, \mathrm{IOR} / \mathrm{L} / \mathrm{PJ} / 6 / 1610$.

${ }^{49}$ Unpublished manuscript by Lalchand Sharma.
} 
The treatment of Indians in Mombasa during the war is best understood through the lens of their insider-outsider status. Throughout the colonial period, relations between Europeans and the local Indian population were shaped by mutual dependency and distrust. The friction between these groups over access to economic power and political participation gained a new dimension in 1914 via the shared imperial war effort. Now existing concerns about the status of this group - both among Europeans and Indians themselves - were amplified by the visible military support provided by the Indian Army in East Africa. For some within local Indian population, this presence was an opportunity to distance themselves further from Africans, and to claim closer alignment with the colonial elite. For the colonial administration, Indian soldiers were connected to fear of a cross-ocean network of anti-colonial Indian activists. Thus, whereas pre-war colonial concerns largely revolved around African resistance to colonial rule, the war and its aftermaths brought a clearer focus to the political challenges to European status and power posed by Indians in East Africa.

\section{Arrivals From the Hinterland}

War also created movement within British East Africa, which occurred primarily through unprecedented demand for African labour. In the Mombasa region alone, tens of thousands of men and women were recruited as porters and labourers by the military. ${ }^{50}$ Combined with a pre-war scarcity, the new demands of the military created an acute shortage of workers in Mombasa. Compounding the situation, war opened up for local Africans many more desirable employment opportunities than conducting hard manual labour, for example as staff for European officers. By 1917, the labour shortage impacted so severely on the workings of the port, that the flow of trade goods, but also of military supplies, was hampered. ${ }^{51}$ Given the importance of the port to the city, and to the colony more broadly, both military and civilian authorities saw the slowdown of transport and merchant shipping as a significant problem, and they were moved to make increasingly intrusive, but generally unsuccessful, interventions into the labour market. ${ }^{52}$

\footnotetext{
${ }^{50}$ Donald C. Savage and J. Forbes Munro, "Carrier corps recruitment in the British East Africa Protectorate, 1914-1918," Journal of African History, 7, 2 (1966), 313-42; Geoffrey Hodges, The Carrier Corps: Military labor in the East African campaign, 1914-1918 (New York/London: Greenwood, 1986).

${ }^{51}$ Letter from D.C. Mombasa to P.C. Mombasa, 1 May 1915, KNA PC/Coast/1/13/119. See also Justin Willis, ““"Men on the Spot," Labor, and the colonial state in British East Africa: The Mombasa water supply, 1911-1917," International Journal of African Historical Studies, 28, 1 (1995), 25-48.

${ }^{52}$ For a detail discussion, see: Willis, Mombasa, the Swahili, 138-9; Cooper, On the African Waterfront, 29-33. For a recent overview, see: Luise White, "Work and discipline on the East African coast," History in Africa, 47 (2019), 1-5.
} 
The labour shortage in Mombasa prompted residents of surrounding rural districts to migrate to the city to avoid military recruitment drives for porters. ${ }^{53}$ Severe famines in $1917 / 18$, as well as the prospect of freedom from traditional societal structures, also drew people to Mombasa, leading to an increase of its population during the war. ${ }^{54}$ While inward migration brought some welcomed relief to the pressured labour market, the changes to the social fabric of Mombasa brought by these arrivals from the hinterland was much less appealing to the colonial authorities. Already prior to the war, driven by paternalistic ideas of 'traditional' African life and a policy of 'divide and rule, ${ }^{55}$ local administrators were engaged in a decade-long attempt to 'disentangle' the various ethnic groups around Mombasa by creating segregated 'tribal' areas and identities. ${ }^{56}$ Authorities were concerned that Mombasa attracted the 'wrong kind of native' and that city life might encourage the development of a more malleable 'Swahili' urban identity, undermining the fine-grained ethnic divisions on which colonial control was based. ${ }^{57}$ Throughout the war years, Mombasa's civil administration was unable to control, let alone count, the number of new arrivals into the city, creating a distinct feeling of loss of power. After the war's end, Provincial Commissioner Hobley lamented that 'every year sees a greater influx of natives foreign to the coast' and that 'the majority [of these migrants] are the undesirable of their own districts.' He concluded that the impact on the town had been so severe that 'it is difficult to write of the social condition of such a heterogeneous population as is found in Mombasa today. 58

The potential for growth of an ethnically-mixed urban 'underclass' through the influx of people from the countryside was a long-running colonial concern. ${ }^{59}$ This concern reflected the glorification of a simple, 'traditional' African life uncorrupted by European

\footnotetext{
${ }^{53}$ Savage and Munro, "Carrier corps recruitment," 328.

${ }^{54}$ Annual Report 1917/18 for Seyidie Province (Mombasa) by P.C. Hobley, n.d. 1918, KNA PC/Coast/1/12/260.

${ }^{55}$ David Cannadine, Ornamentalism: How the British saw their Empire, (London: Penguin, 2002), 61-2; Terence Ranger, "The invention of tradition in colonial Africa," in The Invention of Tradition, eds. Eric Hobsbawm and Terence Ranger (Cambridge: Cambridge University Press 1983), 211-62. For East Africa, see: Charles W. Hobley, Kenya: From chartered company to crown colony: Thirty years of exploration and administration in British East Africa (London: Witherby, 1929), 229-31.

56 Willis, Mombasa, the Swahili, 106-7; Daren Ray, "From constituting communities to dividing districts: The formalization of a cultural border between Mombasa and its hinterland,' in Borderlands in World History, 1700-1914, eds. Paul Readman, Cynthia Radding, and Chad Bryant (Basingstoke: Palgrave Macmillan, 2014), 101-20, esp. 111.

${ }^{57}$ Willis, Mombasa, the Swahili, 110.

${ }^{58}$ Annual Report 1918/19 for Seyidie Province (Mombasa) by P.C. Hobley, 12 Aug. 1919, KNA PC/Coast/1/12/260.

${ }^{59}$ Willis, Mombasa, the Swahili and the Making of the Mijikenda, 129-31; Kefa M. Otiso, "Colonial urbanization and urban management in Kenya," in African Urban Spaces in Historical Perspective, eds. Steven J. Salm and Toyin Falola (Rochester: University of Rochester Press, 2005), 81-2.
} 
civilisation. But embedded within this invented nostalgia was also distrust and disgust of the urban poor with its political and social ambitions.

In Mombasa, the demand on labour inevitably led to a growth in wages. Established white residents complained about the increasing costs for 'houseboys,' cooks, and other servants, blaming inexperienced officers arriving from Europe who were paying inflated prices. ${ }^{60}$ By the end of war, private employers needed to pay 3-4 times average pre-war salaries. ${ }^{61}$ The increasing flow of cash into the city, much of it carried by military staff passing through, saw more and more Africans 'going in for trade' by opening their own shops, further removing themselves from the control of European employers. ${ }^{62}$ The Provincial Commissioner lamented that 'the inhabitant of Mombasa has acquired a standard of living [...] to which the native had never attained before' and that they were now able to indulge in more and more expensive tastes. This 'abnormality' lead the African to 'expect to receive a proportionately higher wage, failing to realise that he, in return, offers probably worse service than his predecessor did years ago. ${ }^{63} \mathrm{He}$ was especially concerned by the number of Africans who, by the end of the war, had acquired sufficient property to enable them to maintain their existence without the necessity of going out to work. These sentiments were shared by European businesses who lobbied the colonial government to introduce harsher labour measures:

Since the outbreak of the war conditions have been accentuated for evil and never before were the natives more irresponsible or impudent. [...] Under the proposed ordinance our idle, irresponsible natives will at last be compelled to do their duty towards the Empire. ${ }^{64}$

Clearly, the white settlers' protest was not only driven by economic self-interest: any elevation to African social status was considered unworthy and unacceptable for them. Emblematic of this was the reaction to discharged African soldiers. With little opportunity to spend their earnings during active service, they passed though Mombasa with the

\footnotetext{
${ }^{60}$ Steinbach, "Between intimacy and violence: Imperial encounters in East Africa during the First World War."

${ }^{61}$ Report on war years by the Dutch consul in Mombasa Bernhard Besseling, 14 Jan. 1920, Bundesarchiv Berlin (hereafter: BA) R 14818, Afrika Generalia. See also: Anthony Clayton and Donald C. Savage, Government and Labour in Kenya, 1895-1963 (London: Frank Cass, 1974), 98-9.

${ }^{62}$ Annual Report 1917/18 for Seyidie Province (Mombasa) by P.C. Hobley, n.d. 1918, KNA PC/Coast/1/12/260.

63 Annual Report 1918/19 for Seyidie Province (Mombasa) by P.C. Hobley, 12 Aug. 1919, KNA PC/Coast/1/12/260.

${ }^{64}$ Leader of British East Africa (21 Aug. 1915). See also: Ian R.G. Spencer, "The First World War and the origins of the dual policy of development in Kenya, 1914-1922," World Development, 9, 8 (1981), 735-48.
} 
accumulated pay of several months. ${ }^{65}$ Despite their service for the Empire's war effort, these men were suspected of 'doing anything else but squandering it in a few days in riotous living in the town' with drunkenness and prostitution. The military authorities in British East Africa became concerned about the possible increase of venereal diseases, demanding stricter controls and regulations from the colonial government. ${ }^{66}$ While colonial officials were also concerned about upholding civic order, they resisted the pressure from the military to criminalise prostitution, fearing an increase in prisoner numbers and thus to public costs. ${ }^{67} \mathrm{~A}$ side effect of the increase of drunkenness and prostitution was an increased ability of African women in Mombasa to economically prosper, amplifying the sense among colonial officials that the war was creating social changes of the wrong kind. ${ }^{6}$

Despite their initial worries of a 'native uprising' in August 1914, the colonial authorities came to doubt that Africans in or around Mombasa would seize the opportunity of the war for organised rebellion. ${ }^{69}$ Apparently, the corrupting impact of war on the working-class, and the potential for disruptive 'outside' influence from Indians, was more of a concern than any political actions by the town's African population. However, this did not stop the arrest of 'undesirables' in response to the outbreak of war. Arrests did not follow a systematic approach, and included men and women from various segments of the city's population, including those 'who have held a somewhat superior status, one for instance an Othman [sic] subject who was a trader, another is a mechanical engineer, and another a blacksmith, all superior men in their way. ${ }^{70}$ The combination of zeal and

\footnotetext{
${ }^{65}$ For a general discussion on the topic, see: Frank Furedi, "The demobilized African soldier and the blow to white prestige," in Guardians of Empire. The armed forces of the colonial powers, 1700-1964, eds. David Killingray and David Omissi (Manchester: Manchester University Press, 1999), 179-97; Richard S. Fogarty and David Killingray, "Demobilization in British and French Africa at the end of the First World War,' Journal of Contemporary History, 50, 1 (2015), 100-23.

${ }^{66}$ Timothy Parsons, "All askaris are family men: Sex, domesticity and discipline in the King's African Rifles, 1902-1964," in Guardians of Empire, eds. Killingray and Omissi, 157-75. Surprisingly, there are no records regarding the behaviour of British soldiers being stationed in Mombasa. Their conduct was perceived as inappropriate in other port cities. See, for example: Philippa Levine, "Battle colors: Race, sex, and colonial soldiery in World War I," Journal of Women's History, 9, 4 (1998), 104-30; Mario M. Ruiz, "Manly spectacles and imperial soldiers in wartime Egypt, 1914-19," Middle Eastern Studies 45, 3 (2009), 351-71.

${ }^{67}$ Letter from P.C. Hobley to General Officer Commanding, Mombasa, 26 May 1915, KNA PC/Coast/1/3/70; Letter from P.C. Hobley to D.C. (Voi), Mombasa, 25 June 1918, KNA PC/Coast/1/3/117.

${ }^{68}$ Margaret Strobel, Muslim Women in Mombasa, 1890-1975 (New Haven CT: Yale University Press, 1979), 138-42; Justin Willis, "Thieves, drunkards and vagrants: Defining crime in colonial Mombasa, 1902-1932," in Policing the Empire: Government, authority and control, 1830-1940, eds. David M. Anderson and David Killingray (Manchester: Manchester University Press, 1991), 219-35.

${ }^{69}$ Cynthia Brantley, The Giriama and Colonial Resistance in Kenya, 1800-1920 (Berkley, CA: University of California Press, 1981), 110-24.

${ }^{70}$ Letter from P.C. Kismayu to P.C. Mombasa, 16 Nov. 1916, KNA PC/Coast/1/1/392
} 
arbitrariness with which these arrests were carried out left even the Provost Marshal of Mombasa flummoxed:

The Mombasa prison is at the present moment full of so called "political prisoners"; the majority of these are "suspects" against whom there appears absolutely no possibility of framing charges under Martial Law. I have made enquiries and can find no definite crimes against any, although a few would appear to the highly suspicious characters. ${ }^{71}$

Despite doubts regarding the legality - and maybe even the wisdom - of these arrests, the local authorities undertook only superficial investigations into the prisoners' circumstances and alleged offences. ${ }^{72}$ Yet, the potential for mingling between different radicals in the city's overcrowded prison in Fort Jesus - especially those of Indian background - led some officials conclude that these measures were counterproductive. Unwilling to release these 'political prisoners,' the government decided to deport them to Kismayo on the Kenyan-Somali border. This remote harbour town transformed into a place of exile for several residents of Mombasa for the remainder of the war. ${ }^{73}$ Although Mombasa's authorities quickly recognised that some of the deportees were innocent victims of defamation, the government was reluctant to let any return to Mombasa until 1919.

The colonial preoccupation with a widespread 'native uprising' may have been the dominant concern at the beginning of the war in August 1914. But, as this peril did not materialise, colonial authorities mostly did not regard Africans as a threat to political stability during the remainder of the war. Yet, the war effort heavily relied on the contribution of African labour. This demand shifted the parameters around the labour market in Mombasa, and in so doing also precipitated shifts in the local African population. This became the primary concern for the colonial administration: namely, how to balance long-standing colonial interests with the shorter-term needs of war. The new fluidity of the labour market, and the influx and mixing of Africans from groups that the authorities would have preferred to remain separate, exposed the weakness of colonial abilities to enforce their power and efficiently control Mombasa's inhabitants.

\footnotetext{
${ }^{71}$ Letter from the Provost Marshal, Mombasa Area to the D.A.A. \& Q.M.G. Base, Mombasa, Dec. 1914, KNA $\mathrm{PC} /$ Coast/1/1/392

${ }^{72}$ Dundas, African Crossroads, 82-3.

${ }^{73}$ Between January 1915 and February 1916, at least 67 prisoners were deported. Attachment to letters from Base Commandant Mombasa to P.C. Kismayu, n.d, KNA PC/Coast/1/1/392.
} 


\section{CONCLUSION}

In 1914 the port city of Mombasa was a diverse, dynamic and cosmopolitan place that shared a tangled history with both its hinterlands and places across the Indian Ocean. The war years pulled at the tangled threads that ran through Mombasa society. Ultimately, the continuing trade that occurred through the war, and particularly the increased demand for cotton, sisal and rubber, meant that the city prospered during this time. Yet, despite this relative prosperity - or perhaps because of it - white residents of the city had a distinct feeling that both Indians and Africans had drifted from their 'assigned space' in the colonial hierarchy. ${ }^{74}$ To some, like Provincial Commissioner Hobley, these upheavals undermined the basis of 'civilised life' in the colony:

To what extent the general lack of sense of proportion engendered by the war contribute to the general state of demoralisation, or whether the whole situation is an inevitable phase of civilisation, it is not easy to determine, but the fact remains that it is a most unpleasing one. ${ }^{75}$

Even before the war, British East Africa had grown increasing fearful of India's influence in the region. Rising migration across the Indian Ocean, political demands - occasionally backed by Delhi and London - by Indian residents, and threats to the economic attainment of European businesses caused frictions across the ocean and across the Empire. The arrival of thousands of Indian soldiers brought with it anxieties - in some cases justified - of cross-ocean solidarity and anti-imperial activity. Suspicions towards Indian communities grew in response to their perceived insider-outsider status. And indeed, Mombasa's Indian population did seize the opportunity provided by the war, and India's involvement in it, to assert their position as loyal imperial subjects, and as legitimate residents of British East Africa, who deserved better status within the colony.

Despite the actively reinforced dichotomy between city and country, port and hinterland, the movement of African people into the town from surrounding areas was an established pattern. War however amplified this movement, and the resulting shift in urban demographics and economic power fed into ever-present imperial concerns about the maintenance of racial hierarchies and colonial power. Although some established African residents of Mombasa, as well as a few 'newcomers,' did benefit economically

\footnotetext{
${ }^{74}$ John Overton, "War and economic development: Settlers in Kenya, 1914-1918,” Journal of African History, 27,1 (1986), 79-103.

${ }^{75}$ Annual Report 1918/19 for Seyidie Province (Mombasa) by P.C. Hobley, 12 Aug. 1919, KNA PC/Coast/1/12/260.
} 
from wartime opportunities, the colonial government also prepared and implemented a series of laws and regulations that consolidated and enhanced Europeans' political and economic supremacy.

While war between European powers may have been the primary reason for all this movement of people, it was, in fact, secondary to the main conflict. For colonial administrations, people needed to be separated, sorted and controlled. The rapid movement of people across borders and social boundaries undermined the administrative capacity to maintain separation, and in so doing destabilised the basis for colonial power. Movement also highlighted uncomfortable dependencies between colonisers and colonised, unsettling the hierarchy on which power relied. Both in their ambivalent attitude about Africans, and their dismissive response to Indian attempts to display imperial solidarity, it is clear that Europeans in Mombasa were primarily focussed on defending their position in the colony, and the racialised structure of society itself, from the intrusions of the First World War. 